native applicants came forward: hence very few unsponsored overseas graduates get the sort of jobs they would like. Most hospital junior appointments are in regional hospitals, and unless the hospital is formally linked with a teaching hospital training is likely to be limited to practical experience ; a good reference at the end of the job is a passport only to another job of the same kind. In practice, therefore, the good training posts are filled by British graduates while the service needs are carried largely by overseas graduates. This is not the result of racial discrimination by hospitals, for coloured graduates of British medical schools meet little prejudice. Some junior posts are in unpopular specialties, such as geriatrics in decaying hospitals in depressed industrial areas ; and it is not surprising that such posts are filled by the applicants who are least equipped to compete for the better postsoften after months of failure to find anything else.

The inescapable conclusion is that junior appointments in many industrial areas are so unattractive that British graduates will not consider them. This fact has had wide publicity, but nevertheless large numbers of overseas doctors are prepared to come to Britain knowing what sort of jobs they are likely to get. This cannot fairly be called exploitation. Medical immigrants enter Britain voluntarily, and they earn more here than they would in their home countries. Furthermore, many overseas graduates are now applying for vacancies in general practice and for consultant appointments, indicating that, for some at least, practice in the N.H.S. is preferable to returning to their own countries, where so often there is a desperate shortage of doctors.

Free movement of doctors around the world is an essential and traditional feature of medicine, and the opportunities for it have never been better. Postgraduate students are always welcome in Britain ; and if doctors from abroad care to try to make a career here good luck to them. But the existing situation-a rising pool of unemployed overseas doctors and a widening gulf between jobs which are worth while and those that can be filled only from the unemployed-should not be allowed to deteriorate. A consultant in a northern mill-town is often faced with the choice of no houseman or one with no previous experience in Britain and with a poor command of English. Should he take on such a candidate, hoping to find him a useful pair of hands while he learns English ? Whose responsibility is it if a tragedy occurs because of misunderstanding or failure in communications ?

The B.M.A. Overseas Committee discussed these problems at its last meeting (Supplement, p. 106) and has asked for talks with the Government as soon as possible. Three steps can and should be taken at once. Firstly, no doctors-except approved postgraduate students-should be allowed into Britain unless their qualifications allow them to be fully registered by the G.M.C. either temporarily or permanently. Secondly, some screening test of knowledge of English and medicine, similar to the American E.C.F.M.G. examination, should be required for all medical immigrants. Finally, appointment committees should refuse to appoint unsuitable applicants to posts in the N.H.S. If no applicants are suitable the conditions of the post must be improved until it attracts candidates of adequate calibre. The state of the hospitals is the Government's responsibility. In the long term it is better that a hospital or a department should close down for a period than be run with poor staff. Only action of this kind will bring home to the public that much of the hospital service is what $\mathrm{Mr}$. Walpole Lewin recently described" as "a crumbling edifice."

Brit. med. 7., Suppl., 1969, 1, 88.

\section{Peril on the Sea}

Trawler fishing and its hazards, the mortality and morbidity of the fishermen, and the medical services provided for them between 1963 and 1965 at Grimsby have recently been described in two articles ${ }^{12}$ by S. R. W. Moore. The author himself went to sea, and the articles give a vivid picture of conditions in the trawling fleet. Moore found that, though the accommodation was almost within the requirements of the international convention, quarters were cramped, noise and vibration reached all parts of the ships, and the continuous movement of these vessels was a frequent cause of accidents.

At Grimsby and some other fishing ports there are dockside medical clinics which provide treatment for sick and injured fishermen. At sea the medical care of the crew is the skipper's responsibility. Both skipper and mate hold first-aid certificates, and the vessel carries a medicine chest and a copy of the Ship Captain's Medical Aid. The skipper may ask for medical advice or summon aid by radio telephone either from the shore or, until recently, from the Icelandic Fishery Protection Patrol ships, or he may put into port to land a sick or injured man. During 1963 a naval vessel gave advice 56 times to Grimsby trawlers and the medical officer boarded 24 times ; 165 Grimsby fishermen were put ashore, 143 at foreign ports, and of these nearly twice as many had injuries as illnesses. In this year there were 14 deaths, three from drowning, two due to suffocation during a fire, one from head injuries, and eight due to natural causes. In a year when there were no founderings or loss of vessels the mortality was $5 \cdot 7 / 1,000$.

Moore found much that was wrong with the medical care of trawlermen. Of 38 fishermen 18 were not registered with a general practitioner. The skippers' and mates' certificates of competence in first aid may have been taken years previously; skippers complained of difficulty in understanding their book of medical guidance and preferred to contact the naval protection vessel. He estimated that when there were full patrols 15 to 20 fishermen a month would receive care from this source, but the squadron has now been withdrawn. Logging of injuries and disease was incomplete and often inaccurate"contusion" was used to describe extensive and severe soft tissue injuries. Tragedies occurred; a mate died of peritonitis ashore, after three days' illness at sea. Unfit men returned to sea after attacks of coronary thrombosis, recurrent hernia, or renal calculi, and continued until they died or became permanently disabled.

Moore has made some important recommendations. New legislation is needed, accidents causing injury or death should be made notifiable and be properly recorded and investigated, and an inspectorate with the same powers as under the Factory, Mines and Quarries and Agriculture Acts should be established. The trawler owners should employ safety officers to investigate accidents and advise on safety. Courses in accident prevention should be arranged and attended by fishermen as part of their duties. More attention should be paid to safety devices in ships, and adequate handrails and safety lines should be installed; warps, winches, and other dangerous machinery should have guards. Better protective clothing should be provided.

There is also a need for an occupational health service for fishermen. Pre-employment and periodic medical examinations should be compulsory, and trawler owners should cooperate by refusing passages to men certified as unfit.

1 Moore, S. R. W., Brit. ๆ. industr. Med., 1969, 26, 1. 
Trawlermen have a fatalistic attitude to sickness and death and pay little attention to safety devices or their own sickness. Health education is needed, and an industrial medical officer should also supervise the first-aid training of skippers and mates, who should attend courses throughout their period of service at sea.

The health and safety of trawlermen are still the subject of much public concern. The interim report of the Board of Trade's Committee of Inquiry which was set up after last winter's three trawler disasters recommended the provision of a support ship to the fishing fleet in the area north of Iceland. The Orsinoe has been at sea throughout the winter carrying meteorological staff, a medical officer, and sick berth attendant, and the results of this innovation will be of great interest ; but only when real changes have been made in conditions at sea will there be a fall in the excessively high mortality rate of fishermen.

\section{Boarding Out}

The adverse effect on patients of prolonged care in large institutions is now well established. Thus it was hardly surprising that the Royal Commission on the Law Relating to Mental Illness and Mental Deficiency, 1957, looked critically on the mental hospitals and supported the concept of community care. The Mental Health Act, 1959, led to the establishment by local health authorities of various types of accommodation for the mentally disordered, including longstay psycho-geriatric hostels, ${ }^{1}$ short-stay hostels, ${ }^{2}$ and boarding out with private landladies. The last practice was not new. Indeed, in 1856 Bucknill, at Devon County Lunatic Asylum, instituted such a scheme for the mentally ill, based on the considerably older system at Gheel in Belgium, and for many years voluntary organizations like the Guardianship Society and the Mental After-care Association had boarded out both the mentally ill and the mentally subnormal.

In his annual report for 1967 the medical officer of health for Exeter ${ }^{3}$ states that many mentally disordered persons may be placed in lodgings provided the landladies are chosen with care and adequate social work support is given. In that city in 1967 there were 112 such people in lodgings, about half of whom were in open employment. Difficulties arose over the low wage obtained ( $£ 6-£ 7$ a week) and the cost of lodgings ( $£ 55 \mathrm{~s}$. a week.) These difficulties have been overcome at Croydon ${ }^{4}$ by the local authority subsidizing the rent of the patients living with private landladies. There a wholetime boarding-out officer was appointed in 1962, whose job was to assess accommodation and match the landlady to the patient. The latter paid directly to the landlady a contribution to his rent assessed according to means, and the local authority made up the difference. In the period 1962 to 1965, 120 patients were placed, and the average total cost

\footnotetext{
1 Jones, K. S., and Milne, V. M., Brit. Hosp. F. soc. Serv. Rev., 1966, 76, 159.

2 Morgan, P., Mth. Bull. Minist. Hlth Lab. Serv., 1964, 23, 224.

Annual Report of the Medical Officer of Health for 1967, Exeter. 1968.

- Wright, S. L., Publ. Hlth (Lond.), 1966, 80, 164.

Brown, G. W., Monck, E. M., Carstairs, G. M., and Wing, J. K., Brit. f. prev. soc. Med., $1962,16,55$.

Report of Committee on Local Authority and Allied Personal Social Services, para. 340 , 1968. H.M.S.O.

- Laugharne, J. R. Case Conference and A.S.W. News, 14, 350.
}

to the local authority, including administration, was $£ 27 \mathrm{~s}$. a week per patient.

Fortunately the majority of patients discharged from mental hospitals live at home with their relatives, though it has been suggested that some patients suffering from schizophrenia might be better living with strangers. ${ }^{5}$ If boardingout schemes are to be extended, there must be close supervision of both landlady and patient by social workers who are part of a joint social work team serving both the hospital and local authority, otherwise prompt return to hospital for any patient who relapses and needs attention will not be available. As the Seebohm report recently emphasized, "There must be no danger of neglect outside the hospital replacing the imaginative and skilful care now provided inside many of them."6 But, since the same report recommends that responsibility for community social services for the mentally disordered should be included in the proposed new social services department, it is difficult to see how adequate liaison with the hospital will be maintained.

Any large-scale expansion of boarding-out of the mentally handicapped must be viewed critically, for much Victorian mental-health legislation was inspired to control the abuse of the "private mad-house" system. But in view of the problems of child care officers in finding homes for normal children $^{7}$ it seems unlikely that there will be any great demand from landladies for middle-aged mentally handicapped lodgers.

\section{Centenarius Scandinavicus}

Bursting with the spirit of inquiry into natural phenomena, the European countries in the nineteenth century saw the foundation of many journals to record the new and exciting observations. Some of these publications still survive, often with a change of title, a greater girth, a more recondite content, and, such is the toll of time, a new editor. Now joining the Lancet and the B.M.F. as a centenarian is the journal we know as Acta Medica Scandinavica, which began in 1869 as Nordiskt Mediciniskt Arkiv.

The founder and first editor of the journal was Axel Key, professor of pathological anatomy at the Karolinska Institute in Stockholm. According to an account of his work in the current issue $^{1}$ he thought the institute was somewhat overshadowed by the universities, notably Uppsala, and that a journal to publish the papers of its members would stimulate them to scientific activity. Such a reason for founding a journal seems entirely appropriate to those spacious days, though now so many pour from the presses that to start one for which there is not an established need is more likely to deserve censure than commendation. However, it was thought that " the incentive would then exist for one and all to provide matter for the journal, and failure to do so would be felt as a neglect of duty." So in 1863 a journal called Medicinskt Arkiv, of which Key was one of three editors, began publication of papers from the institute.

But Key soon had bigger plans and began to think about a journal for all the Scandinavian countries. This idea won support at a meeting in 1868, and the following year saw the closure of the old journal and the birth of its successor,

\footnotetext{
1 Strandell, B., Acta med. scand., 1969, 185, 1.
} 